Financial reporting quality, debt maturity and investment efficiency 
Los documentos de trabajo del Ivie ofrecen un avance de los resultados de las investigaciones económicas en curso, con objeto de generar un proceso de discusión previo a su remisión a las revistas científicas. Al publicar este documento de trabajo, el Ivie no asume responsabilidad sobre su contenido.

Ivie working papers offer in advance the results of economic research under way in order to encourage a discussion process before sending them to scientific journals for their final publication. Ivie's decision to publish this working paper does not imply any responsibility for its content.

La Serie EC, coordinada por Matilde Mas, está orientada a la aplicación de distintos instrumentos de análisis al estudio de problemas económicos concretos.

Coordinated by Matilde Mas, the EC Series mainly includes applications of different analytical tools to the study of specific economic problems.

Todos los documentos de trabajo están disponibles de forma gratuita en la web del Ivie http://www.ivie.es, así como las instrucciones para los autores que desean publicar en nuestras series.

Working papers can be downloaded free of charge from the Ivie website http://www.ivie.es, as well as the instructions for authors who are interested in publishing in our series.

Versión: octubre 2012 / Version: October 2012

Edita / Published by:

Instituto Valenciano de Investigaciones Económicas, S.A.

C/ Guardia Civil, 22 esc. $21^{\circ}$ - 46020 Valencia (Spain) 


\title{
Financial reporting quality, debt maturity and investment efficiency
}

\author{
M. Fuensanta Cutillas and Juan Pedro Sánchez*
}

\begin{abstract}
This study, conducted with a sample of Spanish listed companies during the period 1998-2008, examines the role of financial reporting quality and debt maturity in investment efficiency. The results show that financial reporting quality mitigates the overinvestment problem. Likewise, lower debt maturity can improve investment efficiency, reducing both overinvestment and underinvestment problems. We further find that financial reporting quality and debt maturity are mechanisms with some degree of substitution in enhancing investment efficiency: firms with lower (higher) use of short-term debt, exhibit higher (lower) financial reporting quality effect on investment efficiency.
\end{abstract}

Keywords: investment efficiency, overinvestment, underinvestment, financial reporting quality, debt maturity.

JEL classification: G3, G31.

\section{Resumen}

Este trabajo analiza la influencia de la calidad de la información financiera y la madurez de la deuda en la eficiencia de la inversión para un conjunto de empresas cotizadas españolas en el periodo 1998-2008. Los resultados muestran que la calidad de la información financiera reduce el problema de sobreinversión, mientras que el plazo de la deuda solventa los problemas tanto de sobreinversión como de infrainversión. Además, ambos mecanismos muestran cierto grado de sustitución en la mejora de la eficiencia de la inversión: las empresas con menor (mayor) utilización de deuda a corto plazo, muestran mayor (menor) efecto de la calidad de la información financiera sobre la eficiencia de la inversión.

Palabras clave: eficiencia de la inversión, sobreinversión, infrainversión, calidad de la información financiera, madurez de la deuda.

Clasificación JEL: G3, G31.

\footnotetext{
* M.F. Cutillas and J.P. Sánchez: Universidad de Murcia. Corresponding author: J.P. Sánchez, Universidad de Murcia, Facultad de Economía y Empresa, Campus de Espinardo, 30100 Murcia, tel.: +34 868883807, fax: +34 868887994, e-mail: juanpsb@um.es.
} 


\section{Introduction}

A large body of literature shows that by enhancing financial reporting quality firms can reduce information asymmetries (Bushman and Smith, 2001; Healy and Palepu, 2001). One line of research (Biddle and Hilary, 2006; McNichols and Stubben, 2008; Biddle et al., 2009; Chen et al., 2010) suggests that reducing adverse selection and moral hazard and allowing managers to identify better investment opportunities, higher financial reporting quality increases investment efficiency. Several papers also propose that shorter maturities of debt can be used to mitigate information asymmetry problems (Flannery, 1986; Berger and Udell, 1998; Ortiz-Molina and Penas, 2008): from the perspective of the borrower, because firms signal that they are good firms and may obtain better price conditions in the subsequent renewals of the loans; and from the perspective of the lender, because shorter maturities also enable a better control and monitoring of managers (Diamond 1991, 1993).

Theoretical models (Myers, 1977; Childs et al., 2005) predict that the higher flexibility of shorter maturities is useful in improving investment inefficiencies, although there is limited evidence for this, especially in relation to overinvestment. Based on these premises, the main purpose of this paper is to combine these two mechanisms and analyze the effect of financial reporting quality (FRQ) and debt maturity on investment efficiency in a context of a Code Law country where FRQ is lower than in Anglo-Saxon countries (Leuz et al., 2003; Bhattacharya et al., 2003) and where short-term debt is the major source of external finance. Since a previous study examines "boundary conditions" for the effect of FRQ on investment efficiency, and finds that FRQ influences investment efficiency in private firms in emerging countries (Chen et al., 2010), we also expect to find this association in a sample of listed firms in Spain, where FRQ is expected to be higher. In relation to the role of debt maturity in investment efficiency, to the best of our knowledge this is the first study that empirically examines its effect on both underinvestment and overinvestment. In this sense, Spain is an interesting setting for our research because, due to the less developed capital market than in US and UK and the higher information asymmetry, private debt is the main source of finance for Spanish firms, where banks may play a role in alleviating capital market imperfections (García-Marco and Ocaña, 1999) and the debt maturity structure of companies presents short-term orientation. For instance, whereas in our sample the average value of short-term debt to total liabilities is greater than $60 \%$, in U.S. companies this percentage is around 22\% (Datta et al., 2005). Since these shorter maturities in Spain play, from the lender's perspective, a role as a control device of management performance, and from the borrower's side they also facilitate undertaking positive net present value projects (Myers, 1977), we also expect a positive association between shorter maturities and investment efficiency. 
As an extension of our research, we examine how debt maturity moderates the effect of FRQ on investment efficiency, i.e., whether the effect of FRQ on investment efficiency is increasing or decreasing with the level of debt maturity. We could expect both effects: on the one hand, the reduction of information asymmetry and more reliable accounting numbers due to higher FRQ could add to the better monitoring due to shortterm debt and, as a consequence, the effect of FRQ on investment efficiency should be higher for firms with higher FRQ and shorter maturities; on the other, in firms with higher FRQ lenders will have less need for shorter maturities to monitor managers' behaviour (Bharath et al, 2008; García-Teruel et al, 2010), so under this assumption we would expect the importance of FRQ to increase with longer maturities and to decrease with shorter maturities.

In line with previous studies, we consider different proxies for FRQ that focus on the precision of accounting information: (1) the model of discretionary revenues developed by McNichols and Stubben (2008); (2) the model of discretionary accruals suggested by Kasznik (1999); (3) the Dechow and Dichev (2002) model of accruals quality; (4) finally, we also use an aggregate measure that includes the previous three proxies. Our results show that FRQ reduces overinvestment, while shorter debt maturity mitigates overinvestment and underinvestment. Our findings also demonstrate that the effect of FRQ on investment efficiency is decreasing with shorter maturities, suggesting a substitutive role of FRQ and shorter maturities in reducing information asymmetries and monitoring managerial behaviour to limit expropriation of creditors and minority shareholders.

Our paper contributes to a growing body of literature providing empirical evidence on FRQ and debt maturity roles in improving investment efficiency in a Code Law country where debt maturity is an important device to control managerial behaviour. Our findings suggest that in this context the main concern of creditors is overinvestment, because it is through overinvestment that managers expropriate creditors and minority shareholders, and that this inefficiency can be reduced with both higher FRQ and shorter maturities. With regard to underinvestment, our results suggest that the positive effect of shorter maturities on reducing this inefficiency could be more associated to internal decisions of the firm (Myers, 1977) than to monitoring by creditors. Moreover, this is the first study that analyzes the interaction effect between FRQ and debt maturity on improving investment efficiency and our findings suggest that both mechanisms may play a substitutive role in reducing overinvestment, whereas, unlike previous studies in U.S. and emerging markets (Biddle et al., 2009; Chen et al., 2010) that find that FRQ can solve underinvestment problems, in Spain short-term debt is the main mechanism used to control underinvestment, and FRQ is only relevant when short-term debt level is low (higher maturities). 
The remainder of the paper proceeds as follows. Section 2 reviews the existing literature on investment efficiency and the role of FRQ and debt maturity in investment decisions, and develops our testable hypotheses. Section 3 describes in detail the research design, with the models, measures of variables and the sample. Section 4 shows the results and the final section presents the main conclusions of this paper.

\section{Previous literature and hypotheses development}

\subsection{Determinants of investment efficiency}

Under neo-classical theory, in order to maximize their values firms invest until the marginal benefit equals the marginal cost of this investment (Yoshikawa, 1980; Hayashi, 1982; Abel, 1983). However, in the Keynesian framework (Gordon, 1992; Crotty, 1992), where expected investment will be determined by the preference for growth or for financial security, and in the agency framework (Myers, 1977), which considers information asymmetry problems, firms may deviate from their optimal investment levels and hence suffer from underinvestment (lower investment than expected) or overinvestment (greater investment than expected).

In perfect financial markets, all positive net present value projects (NPV) should be financed and carried out. Nevertheless, there is a significant body of literature that contradicts this assumption (for example, Hubbard, 1998; Bertrand and Mullainathan, 2003). Market imperfections, as well as information asymmetries and agency costs can lead to negative NPV projects being carried out (overinvestment) and to the rejecting of positive NPV projects (underinvestment). According to agency theory, both overinvestment and underinvestment can be explained by the existence of asymmetric information among stakeholders. Jensen and Meckling (1976), Myers (1977) and Myers and Majluf (1984) develop a framework for the role of asymmetric information in investment efficiency through information problems, such as moral hazard and adverse selection. With regard to moral hazard, discrepancy of interests between shareholders and a lack of monitoring of managers may lead to management trying to maximize its personal interests by making investments that may not be suitable for shareholders (Jensen and Meckling, 1976), with the consequence of managerial empire building and overinvestment (Hope and Thomas, 2008). Under adverse selection, better informed managers may overinvest if they sell overpriced securities and achieve excess funds. To avoid this, suppliers of capital can ration the capital or raise its cost, which will lead to the rejection of some profitable projects due to fund constraints (Stiglitz and Weiss, 1981; Lambert et al., 2007) with subsequent underinvestment. 


\subsection{Investment efficiency and financial reporting quality (FRQ)}

From agency theory perspective, there are various control mechanisms to attenuate information asymmetries and information risk and to allow a better supervision of managerial activity that mitigates the opportunistic behaviour of managers, such as financial reporting quality and disclosure (Bushman and Smith, 2001; Healy and Palepu, 2001; Hope and Thomas, 2008). Several studies have analyzed some of these implications, such as the reduction of the cost of capital and cost of debt (Francis et al., 2004 and 2005) and access to the debt market and the effect on its conditions (Bharath et al., 2008), i.e., lower cost, higher debt maturity and lower guarantees in bank financing.

Recently, a line of research has been developed on the effects of FRQ on investment efficiency. Since higher FRQ makes managers more accountable by allowing a better monitoring, and it may reduce information asymmetries and adverse selection, it could diminish overinvestment and underinvestment problems. On the other hand, FRQ could also improve investment efficiency by allowing managers to make better investment decisions through a better identification of projects and more truthful accounting numbers for internal decision makers (Bushman and Smith, 2001; McNichols and Stubben, 2008). Empirically, prior literature argues and finds evidence that financial reporting quality relieves investment-cash flow sensitivity (Biddle and Hilary, 2006) and that earnings management leads to overinvestment because it distorts the information used by managers (McNichols and Stubben, 2008). Based on this discussion, Biddle et al. (2009), for U.S listed firms, and Chen et al (2010), for private firms from emerging markets, examine the effect of FRQ on two inefficient scenarios, overinvestment and underinvestment, and report that higher FRQ helps underinvestment companies to make investments, and overinvestment companies to decrease their investment level. Consistent with this, García Lara et al. (2010) find that conservatism reduces both overinvestment and underinvestment, because it reduces investment-cash flow sensitivity in overinvestment firms and facilitates access to external financing in underinvestment firms.

Based on the above, our first hypothesis is that firms with higher FRQ will show higher investment efficiency in Spain. We differentiate between overinvestment and underinvestment and we analyze the role of FRQ in reducing these inefficient settings.

\subsection{Investment efficiency and debt maturity}

The role of debt in reducing managers' discretion and disciplining their investment decisions has been discussed in the literature (Myers, 1977; Jensen, 1986), and there is some evidence that supports that debt reduces overinvestment (D'Mello and Miranda, 2010). However, the literature has also emphasized the role played by debt maturity 
under information asymmetry, showing that the use of short-term debt is a mechanism that can attenuate informational asymmetries and agency costs between shareholders, creditors and managers. From the borrower's perspective, Flannery (1986) predicts that, under information asymmetry, firms with good projects will prefer shorter maturity to transmit signals to the market and mitigate these information asymmetry problems. From the lender's perspective, when asymmetric information is present, the use of short-term debt is more suitable than long term debt to monitor firms (Diamond, 1991 and 1993; Rajan, 1992). A shortening of debt maturity permits better control of managers, because shorter maturities induce more frequent renegotiations: lenders can ascertain firms' performance during the first period and then they can decide whether to renew or change the contract terms (Ortiz-Molina and Penas, 2008).

As regards investment efficiency, debt maturity can be used to mitigate overinvestment and underinvestment problems: when there are positive NPV projects, firms can finance them with short-term debt and diminish underinvestment problems, because the debt will be liquidated in a short time and the profitability will be entirely for the company (Myers, 1977). In addition, due to the roll-over of short-term debt, debt holders may monitor borrowers better and thus reduce the agency conflict between creditors and borrowers that arises from investment opportunities (Barclay and Smith, 1995; Guedes and Opler, 1996; Parrino and Weisbach, 1999; and Lai, 2011). As regards overinvestment, Childs et al. (2005) predict further that the higher flexibility of shortterm debt to be rolled over and priced according to deviations from a firm-value maximizing strategy can mitigate agency conflicts between stockholder and creditors and thus reduce both underinvestment and overinvestment. Based on this, our second hypothesis is that firms with lower maturities will exhibit higher investment efficiency. The use of short-term debt will help to control underinvestment and overinvestment, because it allows higher financial flexibility for borrowers and greater monitoring for lenders.

As well as checking the isolated effect of financial reporting quality and debt maturity on investment efficiency, we examine their interaction effect, i.e., we investigate whether the effect of FRQ on investment efficiency is increasing or decreasing with the level of debt maturity. In this sense, the effect of FRQ on investment decisions could be mitigated by the presence of short-term debt because through short-term debt creditors can exert their monitoring role on managers to reduce overinvestment and this shortterm debt may be also beneficial for managers to carry out positive investments in underinvestment situations. In contrast, the effect of FRQ on investment efficiency could be greater for those firms with higher short-term debt if both beneficial effects on investment are added. 
Accordingly, our third hypothesis is that the relation between FRQ and investment efficiency depends on the level of debt maturity.

\section{Research design}

\subsection{Model specification}

The model we propose to test the effect of FRQ and short-term debt on investment efficiency is the following:

$$
\begin{aligned}
\text { InvEff }_{\mathrm{i}, \mathrm{t}}= & \beta_{0}+\beta_{1} \text { FRQ }_{\mathrm{i}, \mathrm{t}}+\beta_{2} \text { STDebt }_{\mathrm{i}, \mathrm{t}}+\beta_{3} \text { LnSales }_{\mathrm{i}, \mathrm{t}}+\beta_{4} \text { LnAge }_{\mathrm{i}, \mathrm{t}}+ \\
& \beta_{5} \text { Tang }_{\mathrm{i}, \mathrm{t}}+\beta_{6} \text { StdCFO }_{\mathrm{i}, \mathrm{t}}+\beta_{7} \text { StdSales }_{\mathrm{i}, \mathrm{t}}+\beta_{8} \mathrm{QTobin}_{\mathrm{i}, \mathrm{t}}+ \\
& \beta_{9} \mathrm{Z}_{\mathrm{i}, \mathrm{t}}+\beta_{10} \text { Loss }_{\mathrm{i}, \mathrm{t}}+\beta_{11} \text { CFO_ATA }_{\mathrm{i}, \mathrm{t}}+ \\
& \beta_{12} \text { Opercycle }_{\mathrm{i}, \mathrm{t}}+\sum_{\mathrm{j}} \beta_{\mathrm{j}} \text { Industry dummies }+\varepsilon_{\mathrm{i}, \mathrm{t}}
\end{aligned}
$$

where $I n v E f f_{i, t}$ represents investment efficiency. $F R Q_{i, t}$ represents different proxies of FRQ; $S T D e b t_{i, t}$ is an inverse proxy of debt maturity, the level of short-term debt over total debt (short- and long-term debt). Since our hypotheses predict that both FRQ and STDebt improve investment efficiency, we expect $\beta_{1}$ and $\beta_{2}$ to be positive and significant. The rest are control variables that may influence investment efficiency and innate determinants of FRQ: size, age, tangibility, standard deviation of cash flow and sales, Tobin's Q, Altman's Z-score, presence of losses, cash flow from operations, length of the operating cycle, and industry dummies. Following Petersen (2009), we use t-statistics based on standard errors clustered at the firm and the year level, which are robust to both heteroskedasticity and within-firm serial correlation.

As shown in the literature review section, FRQ and the use of short-term debt can contribute to alleviating asymmetric information problems and improve investment efficiency. Once we test the effects of FRQ and short-term debt on investment efficiency, we will extend the previous analysis to examine if the effect of FRQ on investment efficiency is increasing or decreasing with debt maturity. To check this, we include an interaction effect between FRQ and a dummy variable for our inverse proxy of debt maturity (DumSTDebt $t_{i, t}$ ) which takes the value one if the proportion of shortterm debt over total debt is above the median and zero otherwise:

$$
\begin{aligned}
\text { InvEff }_{\mathrm{i}, \mathrm{t}}= & \beta_{0}+\beta_{1} \text { FRQ }_{\mathrm{i}, \mathrm{t}}+\beta_{2} \text { STDebt }_{\mathrm{i}, \mathrm{t}}+\beta_{3} \mathrm{FRQ}_{\mathrm{i}, \mathrm{t}} * \text { DumSTDebt }_{\mathrm{i}, \mathrm{t}}+ \\
& \beta_{4} \text { LnSales }_{\mathrm{i}, \mathrm{t}}+\beta_{5} \text { LnAge }_{\mathrm{i}, \mathrm{t}}+\beta_{6} \text { Tang }_{\mathrm{i}, \mathrm{t}}+\beta_{7} \text { StdCFO }_{\mathrm{i}, \mathrm{t}}+ \\
& \beta_{8} \text { StdRevenues }_{\mathrm{i}, \mathrm{t}}+\beta_{9} \text { QTobin }_{\mathrm{i}, \mathrm{t}}+\beta_{10} \mathrm{Z}_{\mathrm{i}, \mathrm{t}}+\beta_{11} \text { Loss }_{\mathrm{i}, \mathrm{t}}+ \\
& \beta_{12} \text { CFO_ATA }_{\mathrm{i}, \mathrm{t}}+\beta_{13} \text { Opercycle }_{\mathrm{i}, \mathrm{t}}+\sum_{\mathrm{j}} \beta_{\mathrm{j}} \text { Industry dummies }+\varepsilon_{\mathrm{i}, \mathrm{t}}
\end{aligned}
$$


where FRQ*DumSTDebti,t represents the interaction effect. In this model, $\beta_{1}$ indicates the effect of FRQ on investment efficiency for firms whose level of short-term debt is lower than the median and the sum of the coefficients on the main and interaction effect, $\beta_{1}+\beta_{3}$, represents the FRQ effect on investment efficiency for firms whose level of short-term debt is higher than the median. If the effect of FRQ on investment efficiency is stronger for those firms with lower maturities (higher proportion of short-term debt), $\beta_{3}$ would be positive and significant, whereas if the effect of FRQ on investment efficiency is lower for those firms with shorter maturities, $\beta_{3}$ would be negative and significant.

\subsection{Variable measures}

\subsubsection{Dependent variable: proxy for investment efficiency}

Conceptually, investment efficiency means undertaking all those projects with positive net present value. Biddle et al. (2009), among others, use a model that predicts investment in terms of growth opportunities. Specifically, investment efficiency will exist when there is no deviation from the expected level of investment. However, those companies that invest above their optimal (positive deviations from expected investment) overinvest, while those that do not carry out all profitable projects (negative deviations from expected investment) underinvest.

Following Biddle et al. (2009), in order to estimate the expected level of investment for firm $i$ in year $t$, we specify a model that predicts the level of investment based on growth opportunities (measure by sales growth). Deviations from the model, as reflected in the error term of the investment model, represent the investment inefficiency.

$$
\text { Investment }_{\mathrm{i}, \mathrm{t}}=\beta_{0}+\beta_{1} \text { SalesGrowth }_{\mathrm{i}, \mathrm{t}-1}+\varepsilon_{\mathrm{i}, \mathrm{t}}
$$

where Investment $t_{i, t}$ is the total investment of firm $\mathrm{i}$ in year $\mathrm{t}$, defined as the net increase in tangible and intangible assets and scaled by lagged total assets. SalesGrowth ${ }_{i, t}$ is the rate of change in sales of firm i from $\mathrm{t}-2$ to $\mathrm{t}-1$.

We estimate the investment model cross-sectionally for each year and industry. The residuals from the regression model reflect the deviation from the expected investment level and we use these residuals as a firm-specific proxy for investment inefficiency. A positive residual means that the firm is making investments at a higher rate than expected according to the sales growth, so it will overinvest. In contrast, a negative residual assumes that real investment is less than that expected, so it will represent an underinvestment scenario. Our dependent variable will be the absolute value of the residuals multiplied by -1 , so a higher value means higher efficiency (InvEff $\left.f_{i, t}\right)$. 


\subsubsection{Financial reporting quality (FRQ)}

In order to estimate financial reporting quality we use three different proxies based on accounting precision with respect to fundamentals, according to previous research, as well as a summary statistic, by standardizing these three proxies and taking the average of the three measures (Aggreg i,t $_{\text {) }}$ )

The first measure is obtained following the model proposed by McNichols and Stubben (2008), who consider discretionary revenues as a proxy for earnings management.

$$
\Delta \mathrm{AR}_{\mathrm{i}, \mathrm{t}}=\beta_{0}+\beta_{1} \Delta \text { Sales }_{\mathrm{i}, \mathrm{t}}+\varepsilon_{\mathrm{i}, \mathrm{t}}
$$

where $\Delta A R_{i, t}$ is the annual change in accounts receivable for firm $\mathrm{i}$ in the year t. $\Delta$ Sales $_{i, t}$ represents the annual change in sales revenues for firm $I$ in the year $t$. All terms are scaled by lagged total assets.

The model is estimated separately for each industry-year group. Discretionary revenues are the residuals from equation (4), which represents the change in accounts receivable that is not explained by sales growth. Our first proxy for financial reporting quality will be the absolute value of the residuals multiplied by -1 . Thus, higher values indicate higher FRQ $\left(F R Q_{-} M N S T_{i, t}=-\left|\hat{\varepsilon_{i, t}}\right|\right)$.

The second measure for FRQ is based on the model of discretionary accruals developed by Kasznik (1999), based on Jones (1991):

$$
\mathrm{TA}_{\mathrm{i}, \mathrm{t}}=\beta_{0}+\beta_{1} \Delta \mathrm{Sales}_{\mathrm{i}, \mathrm{t}}+\beta_{2} \mathrm{PPE}_{\mathrm{i}, \mathrm{t}}+\beta_{3} \Delta \mathrm{CFO}_{\mathrm{i}, \mathrm{t}}+\varepsilon_{\mathrm{i}, \mathrm{t}}
$$

where $T A_{i, t}$ is total discretionary accruals, calculated as the change in non-liquid current assets minus the change in current liabilities plus the change in the short-term bank debt, minus depreciation. $\triangle$ Sales $_{i, t}$ is the change in revenues; $P P E_{i, t}$ is property, plant and equipment; $\triangle C F O_{i, t}$ is the change in cash flow from operations. All terms are deflated by lagged total assets.

The model is estimated in its cross-sectional version for each year and industry. The second proxy for financial reporting quality will be the absolute value of residuals from equation (5) multiplied by -1 , so a higher level represents higher quality

$$
\left(F R Q_{-} K A S Z_{i, t}=-\left|\hat{\varepsilon_{i, t}}\right|\right)
$$

Our third proxy is based on the accruals quality model developed by Dechow and Dichev (2002). In this model, current working capital accruals are regressed on cash flow from operations of the previous year, the current year and the subsequent year. 


$$
\mathrm{WCA}_{\mathrm{i}, \mathrm{t}}=\beta_{0}+\beta_{1} \mathrm{CFO}_{\mathrm{i}, \mathrm{t}-1}+\beta_{2} \mathrm{CFO}_{\mathrm{i}, \mathrm{t}}+\beta_{3} \mathrm{CFO}_{\mathrm{i}, \mathrm{t}+1}+\varepsilon_{\mathrm{i}, \mathrm{t}}
$$

where $W C A_{i, t}$ is working capital accruals, calculated as the change in non-liquid current assets, minus the change in current liabilities plus the change in short-term bank debt. $C F O_{i, t-1}, C F O_{i, t}$ and $\mathrm{CFO}_{i, t+1}$ are the cash flow from operations, which are expressed by the difference between net income before extraordinary items and total accruals. All variables are deflated by average total assets.

As in the previous models, the estimation is carried out by year and industry. The residuals from equation (6) reflect the variation in working capital accruals unexplained by cash flow of the current year and adjacent periods. Therefore, the third measure of financial reporting quality will be the absolute value of the residuals multiplied by -1 . Thus a higher value represents higher financial reporting quality.

$$
\left(F R Q_{-} D D_{i, t}=-\left|\hat{\varepsilon}_{i, t}\right|\right) .
$$

Finally, the fourth measure of FRQ, Aggreg $_{i, t}$, is calculated as the average of the standardized values of the three proxies. A higher value means higher financial reporting quality.

\subsubsection{Short-term debt}

To verify the role of short-term debt in investment efficiency, we include STDebt, measured as the ratio of short-term debt (debt that matures before one year) over total debt.

\subsubsection{Control variables}

Following previous studies (Biddle et al., 2009; Chen et al, 2010), we introduce several control variables in our models. As a proxy for size we use the natural logarithm of sales (LnSales); Age is measured as the natural logarithm of the years since the inception of the firm (LnAge); Tangibility (Tang) is the ratio of property, plant and equipment to total assets; we include the standard deviation of cash flow from $\mathrm{t}-2$ to $\mathrm{t}$ $(S t d C F O)$, as well as the volatility of sales in the same period (StdSales); to measure growth options we include Tobin's q (QTobin) as the ratio between the firm's market value of equity and debt over its total assets; to control for the financial solvency of the firm, we employ the firm's financial strength $(Z)$, measured with Altman's z-score (1968), where $\mathrm{Z}$ is defined as:

$$
\mathrm{Z}=0.012 * \mathrm{X}_{1}+0.014 * \mathrm{X}_{2}+0.033 * \mathrm{X}_{3}+0.006 * \mathrm{X}_{4}+0.999 * \mathrm{X}_{5}
$$


where: $\mathrm{X}_{1}=$ Working capital/Total assets; $\mathrm{X}_{2}=$ Retained Earnings/Total assets; $\mathrm{X}_{3}=$ Earnings before interest and taxes/Total assets; $\mathrm{X}_{4}=$ Market value equity/Book value of total debt; $\mathrm{X}_{5}=$ Sales/Total assets.

We include a dummy variable which takes the value one if net income before extraordinary items is negative, and zero otherwise to control if the firm reports losses; moreover, we include the ratio of cash flow to average total assets (CFO_ATA), to capture the cash effect on investment efficiency. Opercycle represents the length of the operating cycle, and finally, we add dummy variables to control for industry effects (Industry dummies).

\subsection{Sample}

We have used three sources to collect our data. From the SABI database, made by Bureau Wan Dijk, we obtained balance sheets and profit and loss accounts. Market value of the company shares were extracted from the Daily Bulletin of the MSE (Madrid Stock Exchange), and interest rates for the robustness analysis were obtained from the Statistic Bulletin of the Bank of Spain.

The estimates of investment efficiency and financial reporting quality variables have been made from a sample of 13,500 firm-year observations from 1997 to 2008, which represent big companies with consolidated information in SABI.

The sample used in our research includes firms listed on the Madrid Stock Exchange from 1998 to 2008. Initially we had a total of 1,039 observations for this period, but the estimates of investment efficiency and financial reporting quality reduced the number of observations considerably. In order to mitigate the influence of outliers we drop observations for 1 and 99 percentiles for all variables, so our final sample consists of 576 firm-year observations from 1998 to 2008. For the accruals quality measure proposed by Dechow and Dichev (2002), a year $(t+1)$ is lost, so for those analyses involving this variable our study is carried out with 500 firm-year observations. 


\section{Results}

\subsection{Descriptive statistics}

Panel A of Table 1 presents the descriptive statistics for the continuous variables, including the mean, median, standard deviation, $10^{\text {th }}$ percentile and $90^{\text {th }}$ percentile. Panel B provides the frequency for the dichotomous variable Loss.

\section{Table 1. Descriptive statistics}

a) Continuous variables

\begin{tabular}{lcccccc}
\hline & $\mathbf{N}$ & Mean & Median & Std. Dev. & Perc. 10 & Perc. 90 \\
\hline InvEff & 576 & -0.086 & -0.048 & 0.135 & -0.200 & -0.010 \\
FRQ_MNST & 576 & -0.038 & -0.023 & 0.051 & -0.082 & -0.003 \\
FRQ_KASZ & 576 & -0.050 & -0.038 & 0.044 & -0.112 & -0.007 \\
FRQ_DD & 500 & -0.034 & -0.028 & 0.029 & -0.069 & -0.005 \\
Aggreg & 500 & 0.088 & 0.239 & 0.599 & -0.645 & 0.670 \\
STDebt & 576 & 0.615 & 0.621 & 0.194 & 0.344 & 0.875 \\
LnSales & 576 & 13.388 & 13.344 & 1.634 & 11.273 & 15.610 \\
LnAge & 576 & 3.793 & 3.840 & 0.560 & 2.995 & 4.482 \\
Tang & 576 & 0.075 & 0.037 & 0.091 & 0.006 & 0.210 \\
StdCFO & 576 & 0.082 & 0.067 & 0.059 & 0.022 & 0.167 \\
StdSales & 576 & 0.075 & 0.060 & 0.063 & 0.016 & 0.159 \\
QTobin & 576 & 1.428 & 1.222 & 0.566 & 0.867 & 2.136 \\
Z & 576 & 2.538 & 2.056 & 1.599 & 1.110 & 4.678 \\
CFO_ATA & 576 & 0.098 & 0.096 & 0.101 & -0.023 & 0.219 \\
Opercycle & 576 & 291.136 & 213.909 & 288.910 & 110.557 & 424.332 \\
\hline
\end{tabular}

b) Dichotomous variable

\begin{tabular}{lllll}
\hline & $\mathbf{0}$ & & $\mathbf{1}$ & \\
\hline Loss & 526 & $91.33 \%$ & 50 & $8.67 \%$ \\
\hline
\end{tabular}

InvEff is the absolute value of residuals of investment model multiplied by $-1 ; F R Q$ MNST is the absolute value of residuals of the model proposed by McNichols and Stubben (2008), multiplied by -1 ; $F R Q \_K A S Z$ is the absolute value of residuals of the Kasznik (1999) model, multiplied by $-1 ; F R Q \_D D$ is the absolute value of residuals of the model developed by Dechow and Dichev (2002), multiplied by -1 ; Aggreg is the summary measurement of FRQ computed as the standardized average of the three FRQ proxies; STDebt is the ratio of short-term debt to total debt; LnSales is the log of sales; LnAge is the log of age; Tang is the tangibility measure calculated as the ratio of tangible assets to total assets; StdCFO is the standard deviation of cash flows from t-2 to t; StdSales is the standard deviation of sales from t-2 to t; QTobin is the ratio of firm's market value plus liabilities to total assets; $Z$ is the degree of solvency; $C F O \quad A T A$ is the ratio of CFO to average total assets; Opercycle is calculated as: (average accounts receivables/sales)*360+(average inventory/cost of goods)*360; Loss is a dummy variable that takes the value 1 if the income before taxes and extraordinary items is negative, and 0 otherwise. 
Investment efficiency (InvEff) in the sample has a mean of -0.086 and a median of -0.048. These values are consistent with previous studies (Chen et al., 2010). In the same way, according to earlier research, all measures of financial reporting quality have the expected values (McNichols and Stubben, 2008; Biddle et al. 2009; Chen et al., 2010). As regards short-term debt, we observe that, on average, $61 \%$ of liabilities are short-term debt. This is consistent with the García-Teruel et al. (2010) study, which showed that Spanish firms hold around $60 \%$ of short-term debt, and contrasts with studies focused on U.S. firms, such as Barclay and Smith (1995) and Datta et al. (2005), where the use of short-term debt is much lower, $28.2 \%$ and $21.46 \%$, respectively.

Table 2 provides the Pearson correlation matrix.

Three out of four financial reporting quality measures show significant positive correlations with investment efficiency, indicating that higher level of FRQ is associated with higher level of investment efficiency. They also show positive and significant correlations with each other, and higher ones with the aggregate measure of FRQ. Likewise, debt maturity structure (STDebt) presents significant positive correlations to investment efficiency, showing that a higher proportion of short-term debt (debt that matures before one year) over total debt is also associated with higher investment efficiency. With respect to FRQ measures, STDebt has a negative correlation with these variables, a result which is also consistent with García-Teruel et al. (2010), who find a positive relation between FRQ and long-term debt. Correlations between independent variables are not high, therefore, collinearity is not likely to be a problem in our study.

\subsection{Regression results}

Table 3 reports the results of the estimation of equation (1) using different financial reporting quality measures. In the first column, we use as FRQ measure the model proposed by McNichols and Stubben (2008); in the second, the model developed by Kasznik (1999); in the third, the model defined by Dechow and Dichev (2002), and finally, in the fourth column, the aggregate measure of FRQ.

Except for the Dechow and Dichev (2002) model, which presents a lower statistical significance (it would be significant at $10 \%$ in a one-tail test), the conclusion is that FRQ enhances investment efficiency since all coefficients of quality measures are positive and significant $(\mathrm{p}<0.01)$. These results are in line with those obtained by Biddle et al. (2009) and Chen et al. (2010), who confirmed the hypotheses that higher financial reporting quality impacts on improving investment efficiency. 


\section{Table 2. Correlation matrix}

\begin{tabular}{|c|c|c|c|c|c|c|c|c|c|c|c|c|c|c|c|c|}
\hline & InvEff & FRQ_MNST & FRQ_KASZ & FRQ_DD & Aggreg & STDebt & LnSales & LnAge & Tang & StdCFO & StdSales & Qtobin & $\mathbf{Z}$ & Loss & CFO_ATA & Opercycle \\
\hline InvEff & 1 & & & & & & & & & & & & & & & \\
\hline FRQ_MNST & $0.361 * * *$ & 1 & & & & & & & & & & & & & & \\
\hline FRQ_KASZ & $0.199 * * *$ & $0.287 * * *$ & 1 & & & & & & & & & & & & & \\
\hline FRQ_DD & -0.004 & $0.077 *$ & $0.446^{* * *}$ & 1 & & & & & & & & & & & & \\
\hline Aggreg & $0.261^{* * *}$ & $0.610^{* * *}$ & $0.801 * * *$ & $0.738^{* * *}$ & 1 & & & & & & & & & & & \\
\hline STDebt & $0.228 * * *$ & $-0.120 * * *$ & $-0.172 * * *$ & $-0.332 * * *$ & $-0.283^{* * *}$ & 1 & & & & & & & & & & \\
\hline LnSales & $-0.120 * * *$ & -0.012 & 0.013 & 0.019 & 0.015 & $-0.243 * * *$ & 1 & & & & & & & & & \\
\hline LnAge & -0.017 & -0.062 & 0.011 & 0.032 & -0.004 & -0.057 & $0.263 * * *$ & 1 & & & & & & & & \\
\hline Tang & $-0.215 * * *$ & -0.047 & -0.009 & -0.029 & -0.039 & $-0.101 * *$ & $0.165 * * *$ & -0.023 & 1 & & & & & & & \\
\hline StdCFO & $-0.078^{*}$ & $-0.221 * * *$ & $-0.283 * * *$ & $-0.282 * * *$ & $-0.364 * * *$ & $0.185 * * *$ & $-0.102 * * *$ & -0.065 & $0.081 * *$ & 1 & & & & & & \\
\hline StdSales & $-0.142 * * *$ & $-0.162 * * *$ & -0.031 & 0.007 & -0.063 & 0.053 & 0.017 & -0.025 & $0.179 * * *$ & $0.173^{* * *}$ & 1 & & & & & \\
\hline Qtobin & $0.073^{*}$ & 0.011 & $-0.120 * * *$ & $-0.342 * * *$ & $-0.205^{* * *}$ & $0.192 * * *$ & 0.040 & -0.028 & $0.229 * * *$ & $0.157 * * *$ & -0.049 & 1 & & & & \\
\hline $\mathbf{Z}$ & $0.200 * * *$ & $0.099 * *$ & $-0.103 * * *$ & $-0.357 * * *$ & $-0.159 * * *$ & $0.442 * * *$ & $-0.128 * * *$ & $-0.156 * * *$ & $0.099 * *$ & $0.123 * * *$ & -0.028 & $0.692 * * *$ & 1 & & & \\
\hline Loss & -0.010 & 0.016 & -0.040 & $-0.086^{* *}$ & -0.066 & $-0.099 * *$ & $-0.168^{* * *}$ & -0.008 & -0.008 & 0.050 & $0.116^{* * *}$ & -0.041 & $-0.138^{* * *}$ & 1 & & \\
\hline CFO_ATA & 0.072 & $0.080^{*}$ & -0.033 & $-0.219^{* * *}$ & -0.073 & $0.169 * * *$ & $0.171 * * *$ & $-0.099 * *$ & 0.028 & -0.013 & 0.017 & $0.300^{* * *}$ & $0.377 * * *$ & $-0.276^{* * *}$ & 1 & \\
\hline Opercycle & 0.063 & 0.028 & -0.030 & 0.060 & 0.021 & 0.044 & $-0.374 * * *$ & 0.035 & $-0.211 * * *$ & 0.031 & $-0.150^{* * *}$ & 0.034 & -0.024 & 0.021 & $-0.212 * * *$ & 1 \\
\hline
\end{tabular}

$* * *, * *, *$ denote significance at the $1 \%, 5 \%$ and $10 \%$ level, respectively. See Table 1 for definitions of variables. 
Table 3. Regression of investment efficiency on FRQ, debt maturity and control variables

\begin{tabular}{|c|c|c|c|c|}
\hline \multicolumn{5}{|c|}{ Dependent variable: InvEff } \\
\hline & 1 & 2 & 3 & 4 \\
\hline FRQ_MNST & $\begin{array}{c}0.961 * * * \\
(9.28)\end{array}$ & & & \\
\hline FRQ_KASZ & & $\begin{array}{c}0.778^{* * *} \\
(2.68)\end{array}$ & & \\
\hline FRQ_DD & & & $\begin{array}{l}0.474 \\
(1.42)\end{array}$ & \\
\hline Aggreg & & & & $\begin{array}{c}0.086^{* * *} \\
(3.49)\end{array}$ \\
\hline STDebt & $\begin{array}{c}0.159 * * * \\
(4.97)\end{array}$ & $\begin{array}{c}0.146 * * * \\
(3.38)\end{array}$ & $\begin{array}{c}0.151^{* * * *} \\
(3.23)\end{array}$ & $\begin{array}{c}0.199 * * * \\
(4.22)\end{array}$ \\
\hline LnSales & $\begin{array}{l}-0.002 \\
(-0.57)\end{array}$ & $\begin{array}{l}-0.001 \\
(-0.19)\end{array}$ & $\begin{array}{l}-0.003 \\
(-0.56)\end{array}$ & $\begin{array}{l}-0.001 \\
(-0.18)\end{array}$ \\
\hline LnAge & $\begin{array}{l}0.011 \\
(1.16)\end{array}$ & $\begin{array}{l}0.008 \\
(1.14)\end{array}$ & $\begin{array}{l}0.009 \\
(1.12)\end{array}$ & $\begin{array}{l}0.011 \\
(1.16)\end{array}$ \\
\hline Tang & $\begin{array}{c}-0.286 * * * \\
(-4.67)\end{array}$ & $\begin{array}{c}-0.300 * * * \\
(-3.48)\end{array}$ & $\begin{array}{c}-0.334 * * * \\
(-3.12)\end{array}$ & $\begin{array}{c}-0.342 * * * \\
(-3.79)\end{array}$ \\
\hline StdCFO & $\begin{array}{l}-0.051 \\
(-0.56)\end{array}$ & $\begin{array}{l}-0.069 \\
(-0.52)\end{array}$ & $\begin{array}{l}-0.194 \\
(-1.06)\end{array}$ & $\begin{array}{l}0.025 \\
(0.19)\end{array}$ \\
\hline StdSales & $\begin{array}{l}-0.119 \\
(-1.37)\end{array}$ & $\begin{array}{c}-0.206^{* *} \\
(-2.02)\end{array}$ & $\begin{array}{c}-0.174^{*} \\
(-1.79)\end{array}$ & $\begin{array}{c}-0.155^{*} \\
(-1.79)\end{array}$ \\
\hline QTobin & $\begin{array}{l}-0.001 \\
(-0.05)\end{array}$ & $\begin{array}{l}-0.007 \\
(-0.86)\end{array}$ & $\begin{array}{l}-0.002 \\
(-0.25)\end{array}$ & $\begin{array}{l}0.005 \\
(0.54)\end{array}$ \\
\hline $\mathbf{Z}$ & $\begin{array}{l}0.009 * \\
(1.74)\end{array}$ & $\begin{array}{c}0.018^{* * *} \\
(3.96)\end{array}$ & $\begin{array}{c}0.017 * * * \\
(3.51)\end{array}$ & $\begin{array}{c}0.013 * * \\
(2.54)\end{array}$ \\
\hline Loss & $\begin{array}{l}0.013 \\
(0.67)\end{array}$ & $\begin{array}{l}0.032 \\
(1.55)\end{array}$ & $\begin{array}{l}0.028 \\
(1.02)\end{array}$ & $\begin{array}{l}0.037 \\
(1.45)\end{array}$ \\
\hline CFO_ATA & $\begin{array}{l}-0.037 \\
(-0.64)\end{array}$ & $\begin{array}{l}0.005 \\
(0.09)\end{array}$ & $\begin{array}{l}-0.006 \\
(0.17)\end{array}$ & $\begin{array}{l}-0.009 \\
(-0.16)\end{array}$ \\
\hline Opercycle & $\begin{array}{c}2.31 \cdot 10^{-6} \\
(0.11)\end{array}$ & $\begin{array}{c}1.76 \cdot 10^{-5} \\
(1.26)\end{array}$ & $\begin{array}{c}-6.33 \cdot 10^{-7} \\
(-0.04)\end{array}$ & $\begin{array}{c}1.55 \cdot 10^{-7} \\
(0.01)\end{array}$ \\
\hline Intercept & $\begin{array}{c}-0.158^{* *} \\
(-2.42)\end{array}$ & $\begin{array}{c}-0.167 * * \\
(-2.02)\end{array}$ & $\begin{array}{l}-0.160 \\
(-1.57)\end{array}$ & $\begin{array}{c}-0.262^{* *} \\
(-2.50)\end{array}$ \\
\hline Industry dummies & Yes & Yes & Yes & Yes \\
\hline $\mathbf{R}^{2}$ & 0.261 & 0.203 & 0.154 & 0.253 \\
\hline $\mathbf{F}$ & 4.08 & 3.28 & 2.80 & 3.30 \\
\hline $\mathbf{p}>\mathbf{F}$ & 0.000 & 0.000 & 0.000 & 0.000 \\
\hline Obs. & 576 & 576 & 500 & 500 \\
\hline
\end{tabular}

$* * *, * *, *$ denote significance at the $1 \%, 5 \%$ and $10 \%$ level, respectively. See Table 1 for definitions of variables. 
Additionally, in equation (1) we test the debt maturity effect on investment efficiency. In all four models, the STDebt variable presents a positive and significant coefficient $(p<0.01)$, showing that shorter maturities increase investment efficiency, which is consistent with our hypothesis.

In terms of the control variables, in all our models tangibility (Tang) has a significant and negative coefficient $(\mathrm{p}<0.01)$, showing that a higher volume of tangible assets leads to lower investment efficiency. Moreover, higher financial strength, measured by $\mathrm{Z}$, is associated with higher investment efficiency, whereas higher sales volatility has a negative impact on investment efficiency. All variables have the expected signs and are consistent with previous studies.

Secondly, we perform our analysis of investment efficiency distinguishing two alternative scenarios, overinvestment and underinvestment, represented by positive and negative residuals in the investment efficiency model. We consider as dependent variables the absolute values of positive deviations with regard to expected investment multiplied by -1 (higher values indicate lower overinvestment, that is, higher efficiency) and absolute values of negative deviations with regard to expected investment multiplied by -1 (higher values indicate lower underinvestment, that is, higher efficiency). Table 4 presents the results for investment efficiency in overinvestment and underinvestment scenarios. The first four models (1-4) correspond to regressions using overinvestment as dependent variable, while the remaining models (5-8) use underinvestment as dependent variable.

In an overinvestment situation, financial reporting quality contributes to decreasing investment excess. We note that all coefficients are positive and significant $(p<0.01)$, indicating that higher FRQ reduces the overinvestment problem, that is, it is a mechanism that help firms to decrease their investment until they achieve their optimal level. These findings seem to support the view that higher FRQ helps control the overinvestment carried out by management in order to expropriate minority shareholders and creditors. However, in an underinvestment scenario, financial reporting quality has no significant effect on enhancing efficiency, suggesting that in those firms with lower investment than expected FRQ is not effective in increasing the investment level. Regarding debt maturity, we obtain, in general, that lower debt maturity contributes to improving investment efficiency by decreasing both overinvestment and underinvestment. This evidence is consistent with Childs et al. (2005).

Control variables suggest that for those firms which invest above their optimal level, a higher level of non-current asset leads to greater inefficiency, while this effect does not appear in those firms which invest below the optimal level. 
Table 4. Regression of overinvestment and underinvestment on FRQ, debt maturity and control variables

Overinvestment (1-4); Underinvestment (5-8)

\begin{tabular}{|c|c|c|c|c|c|c|c|c|}
\hline & 1 & 2 & 3 & 4 & 5 & 6 & 7 & 8 \\
\hline FRQ_MNST & $\begin{array}{c}1.241 * * * \\
(5.82)\end{array}$ & & & & $\begin{array}{l}0.060 \\
(0.47)\end{array}$ & & & \\
\hline FRQ_KASZ & & $\begin{array}{c}1.074 * * * \\
(2.88)\end{array}$ & & & & $\begin{array}{l}-0.007 \\
(-0.07)\end{array}$ & & \\
\hline FRQ_DD & & & $\begin{array}{c}1.031 * * \\
(2.05)\end{array}$ & & & & $\begin{array}{l}-0.056 \\
(-0.71)\end{array}$ & \\
\hline Aggreg & & & & $\begin{array}{c}0.131^{* * *} \\
(7.90)\end{array}$ & & & & $\begin{array}{l}0.002 \\
(0.31)\end{array}$ \\
\hline STDebt & $\begin{array}{c}0.253 * * * \\
(3.10)\end{array}$ & $\begin{array}{c}0.202^{* * *} \\
(2.88)\end{array}$ & $\begin{array}{c}0.229 * * * \\
(3.05)\end{array}$ & $\begin{array}{c}0.280 * * * \\
(3.08)\end{array}$ & $\begin{array}{l}0.363 \\
(1.37)\end{array}$ & $\begin{array}{l}0.342 \\
(1.30)\end{array}$ & $\begin{array}{c}0.049 * * \\
(2.06)\end{array}$ & $\begin{array}{c}0.053 * \\
(1.91)\end{array}$ \\
\hline LnSales & $\begin{array}{l}-0.003 \\
(-0.30)\end{array}$ & $\begin{array}{l}-0.004 \\
(-0.37)\end{array}$ & $\begin{array}{l}-0.007 \\
(-0.57)\end{array}$ & $\begin{array}{l}-0.004 \\
(-0.28)\end{array}$ & $\begin{array}{c}-0.006 * * \\
(-2.26)\end{array}$ & $\begin{array}{c}-0.006 * * \\
(-2.08)\end{array}$ & $\begin{array}{l}-0.004 \\
(-1.50)\end{array}$ & $\begin{array}{l}-0.004 \\
(-1.45)\end{array}$ \\
\hline LnAge & $\begin{array}{l}0.022 \\
(1.16)\end{array}$ & $\begin{array}{l}0.019 \\
(0.85)\end{array}$ & $\begin{array}{l}0.017 \\
(1.10)\end{array}$ & $\begin{array}{l}0.015 \\
(0.66)\end{array}$ & $\begin{array}{c}0.009 * * \\
(2.15)\end{array}$ & $\begin{array}{c}0.009 * * \\
(1.98)\end{array}$ & $\begin{array}{l}0.006 \\
(1.30)\end{array}$ & $\begin{array}{l}0.006 \\
(1.39)\end{array}$ \\
\hline Tang & $\begin{array}{c}-0.375^{* * *} \\
(-5.20)\end{array}$ & $\begin{array}{c}-0.410 * * * \\
(-6.15)\end{array}$ & $\begin{array}{c}-0.378 * * * \\
(-6.87)\end{array}$ & $\begin{array}{c}-0.419 * * * \\
(-7.70)\end{array}$ & $\begin{array}{l}-0.004 \\
(-0.08)\end{array}$ & $\begin{array}{l}-0.001 \\
(0.03)\end{array}$ & $\begin{array}{l}-0.033 \\
(-0.77)\end{array}$ & $\begin{array}{l}-0.035 \\
(-0.78)\end{array}$ \\
\hline StdCFO & $\begin{array}{l}-0.306 \\
(-1.07)\end{array}$ & $\begin{array}{l}-0.238 \\
(-0.85)\end{array}$ & $\begin{array}{l}-0.489 \\
(-1.22)\end{array}$ & $\begin{array}{l}-0.147 \\
(-0.59)\end{array}$ & $\begin{array}{l}-0.042 \\
(-1.00)\end{array}$ & $\begin{array}{l}-0.058 \\
(-1.60)\end{array}$ & $\begin{array}{l}-0.048 \\
(-1.16)\end{array}$ & $\begin{array}{l}-0.037 \\
(-0.99)\end{array}$ \\
\hline StdSales & $\begin{array}{l}-0.216 \\
(-1.31)\end{array}$ & $\begin{array}{c}-0.345^{*} \\
(-1.73)\end{array}$ & $\begin{array}{l}-0.320 \\
(-1.36)\end{array}$ & $\begin{array}{l}-0.275 \\
(-1.41)\end{array}$ & $\begin{array}{l}-0.014 \\
(-0.25)\end{array}$ & $\begin{array}{l}-0.014 \\
(-0.28)\end{array}$ & $\begin{array}{l}-0.005 \\
(-0.09)\end{array}$ & $\begin{array}{l}-0.007 \\
(-0.12)\end{array}$ \\
\hline QTobin & $\begin{array}{l}0.010 \\
(0.40)\end{array}$ & $\begin{array}{l}0.005 \\
(0.19)\end{array}$ & $\begin{array}{l}-0.020 \\
(-0.77)\end{array}$ & $\begin{array}{l}0.028 \\
(0.90)\end{array}$ & $\begin{array}{l}-0.002 \\
(-0.42)\end{array}$ & $\begin{array}{l}-0.002 \\
(-0.44)\end{array}$ & $\begin{array}{c}1.44 \cdot 10^{-4} \\
(0.04)\end{array}$ & $\begin{array}{l}0.001 \\
(0.17)\end{array}$ \\
\hline $\mathbf{Z}$ & $\begin{array}{l}0.011 \\
(0.85)\end{array}$ & $\begin{array}{l}0.019 \\
(1.57)\end{array}$ & $\begin{array}{c}0.031 * * * \\
(2.78)\end{array}$ & $\begin{array}{l}0.012 \\
(0.82)\end{array}$ & $\begin{array}{l}0.002 \\
(0.96)\end{array}$ & $\begin{array}{l}0.003 \\
(1.33)\end{array}$ & $\begin{array}{l}0.001 \\
(0.59)\end{array}$ & $\begin{array}{l}0.002 \\
(0.67)\end{array}$ \\
\hline Loss & $\begin{array}{l}0.002 \\
(0.04)\end{array}$ & $\begin{array}{l}0.033 \\
(0.59)\end{array}$ & $\begin{array}{l}0.040 \\
(0.55)\end{array}$ & $\begin{array}{l}0.043 \\
(0.59)\end{array}$ & $\begin{array}{l}-0.010 \\
(-1.00)\end{array}$ & $\begin{array}{l}-0.010 \\
(-0.94)\end{array}$ & $\begin{array}{l}-0.001 \\
(-0.10)\end{array}$ & $\begin{array}{c}2.97 \cdot 10^{-4} \\
(0.03)\end{array}$ \\
\hline CFO_ATA & $\begin{array}{l}-0.115 \\
(-0.95)\end{array}$ & $\begin{array}{l}0.049 \\
(0.45)\end{array}$ & $\begin{array}{l}0.063 \\
(0.65)\end{array}$ & $\begin{array}{l}0.021 \\
(0.15)\end{array}$ & $\begin{array}{l}0.055 \\
(1.20)\end{array}$ & $\begin{array}{l}0.053 \\
(1.18)\end{array}$ & $\begin{array}{l}0.033 \\
(0.70)\end{array}$ & $\begin{array}{l}0.033 \\
(0.70)\end{array}$ \\
\hline Opercycle & $\begin{array}{c}-2.49 \cdot 10^{-6} \\
(-0.07)\end{array}$ & $\begin{array}{c}4.51 \cdot 10^{-5} \\
(1.53)\end{array}$ & $\begin{array}{c}2.29 \cdot 10^{-5} \\
(0.38)\end{array}$ & $\begin{array}{c}2.89 \cdot 10^{-5} \\
(0.49)\end{array}$ & $\begin{array}{c}-2.18 \cdot 10^{-6} \\
(-0.29)\end{array}$ & $\begin{array}{c}-1.28 \cdot 10^{-6} \\
(0.35)\end{array}$ & $\begin{array}{c}-1.07 \cdot 10^{-6} \\
(-0.12)\end{array}$ & $\begin{array}{c}-1.71 \cdot 10+^{-6} \\
(-0.19)\end{array}$ \\
\hline Intercept & $\begin{array}{l}-0.231 \\
(-1.64)\end{array}$ & $\begin{array}{l}-0.202 \\
(-1.51)\end{array}$ & $\begin{array}{l}-0.163 \\
(-1.02)\end{array}$ & $\begin{array}{c}-0.325 * * \\
(-2.27)\end{array}$ & $\begin{array}{l}-0.029 \\
(-0.71)\end{array}$ & $\begin{array}{l}-0.034 \\
(-0.75)\end{array}$ & $\begin{array}{l}-0.050 \\
(-1.09)\end{array}$ & $\begin{array}{l}-0.056 \\
(-1.09)\end{array}$ \\
\hline Industry dummies & Yes & Yes & Yes & Yes & Yes & Yes & Yes & Yes \\
\hline $\mathbf{R}^{2}$ & 0.355 & 0.273 & 0.217 & 0.352 & 0.096 & 0.094 & 0.092 & 0.091 \\
\hline $\mathbf{F}$ & 5.33 & 3.60 & 3.78 & 4.32 & 2.40 & 2.21 & 1.93 & 1.93 \\
\hline $\mathbf{p}>\mathbf{F}$ & 0.000 & 0.000 & 0.000 & 0.000 & 0.01 & 0.001 & 0.012 & 0.013 \\
\hline Obs. & 275 & 275 & 230 & 230 & 301 & 301 & 270 & 270 \\
\hline
\end{tabular}

$* * *, * *, *$ denote significance at the $1 \%, 5 \%$ and $10 \%$ level, respectively. See Table 1 for definitions of variables. 


\subsection{Analysis extension}

In this section we extend the previous analyses by testing whether higher use of shortterm debt decreases or increases the financial reporting quality effect on investment efficiency. We defined DumSTDebt, as a dummy variable that takes the value one if short-term debt is higher than the median, and zero if it is lower than the median. In Table 5 we estimate equation (2) including the interaction effect between the aggregate measure of FRQ and short-term debt.

Table 5. Regression of investment efficiency on FRQ, debt maturity, and interaction (I)

\begin{tabular}{|c|c|c|c|}
\hline & InvEff & Overinvestment Eff. & Underinvestment Eff. \\
\hline \multirow[t]{2}{*}{ Aggreg } & $0.160 * * *$ & $0.182 * * *$ & $0.028^{*}$ \\
\hline & $(4.14)$ & $(5.11)$ & $(1.92)$ \\
\hline \multirow[t]{2}{*}{ STDebt } & $0.232 * * *$ & $0.286 * * *$ & $0.073 * *$ \\
\hline & $(5.84)$ & $(3.95)$ & $(2.53)$ \\
\hline \multirow[t]{2}{*}{ FRQ*DumSTDebt } & $-0.132 * *$ & $-0.123 * *$ & $-0.033 * *$ \\
\hline & $(-3.05)$ & $(-2.16)$ & $(-2.37)$ \\
\hline \multirow[t]{2}{*}{ LnSales } & -0.003 & -0.004 & $-0.005 *$ \\
\hline & $(-0.59)$ & $(-0.35)$ & $(-1.67)$ \\
\hline \multirow[t]{2}{*}{ LnAge } & 0.017 & 0.022 & $0.007 * *$ \\
\hline & $(1.26)$ & $(0.82)$ & $(2.21)$ \\
\hline \multirow[t]{2}{*}{ Tang } & $-0.293 * * *$ & $-0.385 * * *$ & -0.029 \\
\hline & $(-4.21)$ & $(-6.61)$ & $(-0.71)$ \\
\hline \multirow[t]{2}{*}{ StdCFO } & -0.023 & -0.167 & -0.041 \\
\hline & $(-0.16)$ & $(-0.72)$ & $(-0.87)$ \\
\hline \multirow[t]{2}{*}{ StdSales } & $-0.182 * *$ & -0.280 & -0.010 \\
\hline & $(-2.01)$ & $(-1.41)$ & $(-0.20)$ \\
\hline \multirow[t]{2}{*}{ QTobin } & 0.001 & 0.018 & $1.239 \cdot 10^{-4}$ \\
\hline & $(0.16)$ & $(0.71)$ & $(0.03)$ \\
\hline \multirow[t]{2}{*}{$\mathbf{Z}$} & $0.012 * * *$ & $0.017^{*}$ & 0.001 \\
\hline & $(3.11)$ & $(1.80)$ & $(0.54)$ \\
\hline \multirow[t]{2}{*}{ Loss } & 0.038 & 0.049 & 0.001 \\
\hline & (1.44) & $(0.65)$ & $(0.13)$ \\
\hline \multirow[t]{2}{*}{ CFO_ATA } & -0.020 & -0.007 & 0.032 \\
\hline & $(-0.32)$ & $(-0.04)$ & $(0.74)$ \\
\hline \multirow[t]{2}{*}{ Opercycle } & $7.43 \cdot 10^{-6}$ & $4.00 \cdot 10^{-5}$ & $-1.09 \cdot 10^{-6}$ \\
\hline & $(0.38)$ & $(0.73)$ & $(-0.13)$ \\
\hline \multirow[t]{2}{*}{ Intercept } & $-0.273 * * *$ & $-0.328 * *$ & -0.068 \\
\hline & $(-2.67)$ & $(-2.13)$ & $(-1.24)$ \\
\hline Industry dummies & Yes & Yes & Yes \\
\hline Test $B_{1}+B_{3}$ & $11.51 * * *$ & $4.85 * *$ & 0.91 \\
\hline $\mathbf{R}^{2}$ & 0.322 & 0.390 & 0.110 \\
\hline $\mathbf{F}$ & 3.886 & 4.77 & 2.48 \\
\hline $\mathbf{p}>\mathbf{F}$ & 0.000 & 0.000 & 0.001 \\
\hline Obs. & 500 & 230 & 270 \\
\hline
\end{tabular}

$* * *, * *, *$ denote significance at the $1 \%, 5 \%$ and $10 \%$ level, respectively. See Table 1 for definitions of variables.

$F R Q$ variable is the aggregate measure of three proxies; DumSTDebt takes value 1 if short-term debt is higher than the median (0.62), and 0 otherwise. For the remaining variables see Table1. 
As we have obtained in previous models, both FRQ and STDebt have positive and significant coefficients $(\mathrm{p}<0.01)$. For those firms that have lower STDebt, the coefficient of FRQ is $0.16(p<0.01)$, whereas for those firms with higher short-term debt, the financial reporting quality effect is lower $\left(\beta_{3}<0\right)$, and its effect is given by $\beta_{1}+\beta_{3}=0.03(\mathrm{p}<0.01)$. Therefore, for firms which have lower short-term finance, the FRQ effect (0.16) on investment efficiency is higher than for firms with a higher shortterm debt level (0.03).

These findings prove that FRQ and STDebt are mechanisms with some degree of substitution in improving investment efficiency: a firm can mitigate investment inefficiency by preparing information with higher quality or by reducing debt maturity.

If we divide our sample into overinvestment and underinvestment, the results show that in firms that overinvest and that have higher short-term debt, the financial reporting quality effect on investment efficiency is given by $\beta_{1}+\beta_{3}=0.06(p<0.01)$, with $\beta_{3}<0$. Instead, for firms that have a lower short-term debt level, the financial reporting quality effect is positive and significant and it is higher than for firms with higher STDebt, $0.18>0.06$. These conclusions in an overinvestment situation confirm the results obtained in the general model of investment efficiency.

With respect to the underinvestment scenario, we confirm that for firms that have a higher short-term debt level, financial reporting quality effect is not significant. Nevertheless, for those firms with lower short-term debt level, financial reporting quality has a positive effect on enhancing underinvestment. This suggests that FRQ has importance, although only when the short-term debt level is low.

\subsection{Robustness checks}

In this section we conduct additional robustness tests of the reported results.

\subsubsection{Alternative investment efficiency model}

We re-estimate the expected level of investment following the model developed by Chen et al. (2010). This model adds an independent dummy variable (NEG) because the authors consider that the relation between investment and sales growth could differ in the case of positive or negative growth.

$$
\text { Investment }_{\mathrm{i}, \mathrm{t}}=\beta_{0}+\beta_{1} \mathrm{NEG}_{\mathrm{i},-1-1}+\Delta \text { SalesGrowth }_{\mathrm{i}, \mathrm{t}-1}+\beta_{3} \mathrm{NEG}_{\mathrm{i},-1-1} * \Delta \operatorname{SalesGrowth}_{\mathrm{i},-1-1}+\varepsilon_{\mathrm{i}, \mathrm{t}}
$$

where $N E G_{i, t-1}$ is a dummy variable that takes value 1 for negative sales growth, and 0 otherwise, and the rest of variables are defined as above. 
The results of estimating equation (1) using this investment efficiency are similar to those previously reported, as displayed in Table 6.

Table 6. Regression of investment efficiency (model of Chen et al., 2010) on FRQ, debt maturity and control variables

\begin{tabular}{|c|c|c|c|}
\hline & InvEff & Overinvestment & Underinvestment \\
\hline \multirow[t]{2}{*}{ Aggreg } & $0.086^{* * *}$ & $0.131 * * *$ & 0.003 \\
\hline & $(3.60)$ & $(8.00)$ & $(0.46)$ \\
\hline \multirow[t]{2}{*}{ STDebt } & $0.199 * * *$ & $0.278 * * *$ & $0.058 * *$ \\
\hline & $(4.21)$ & $(3.01)$ & $(2.06)$ \\
\hline \multirow[t]{2}{*}{ LnSales } & -0.001 & -0.003 & -0.004 \\
\hline & $(-0.18)$ & $(-0.26)$ & $(-1.52)$ \\
\hline \multirow[t]{2}{*}{ LnAge } & 0.007 & 0.013 & 0.001 \\
\hline & $(0.84)$ & $(0.56)$ & $(0.53)$ \\
\hline \multirow[t]{2}{*}{ Tang } & $-0.328 * * *$ & $-0.403 * * *$ & -0.037 \\
\hline & $(-3.64)$ & $(-6.98)$ & $(-0.74)$ \\
\hline \multirow[t]{2}{*}{ StdCFO } & 0.022 & -0.139 & -0.043 \\
\hline & $(0.17)$ & $(-0.55)$ & $(-1.07)$ \\
\hline \multirow[t]{2}{*}{ StdSales } & $-0.150 *$ & -0.277 & 0.002 \\
\hline & $(-1.78)$ & $(-1.41)$ & $(0.04)$ \\
\hline \multirow{2}{*}{ QTobin } & 0.004 & 0.027 & -0.001 \\
\hline & $(0.39)$ & $(0.88)$ & $(-0.34)$ \\
\hline \multirow[t]{2}{*}{$\mathbf{Z}$} & $0.014 * *$ & 0.011 & 0.003 \\
\hline & $(2.62)$ & $(0.82)$ & (1.16) \\
\hline \multirow[t]{2}{*}{ Loss } & 0.039 & 0.045 & 0.004 \\
\hline & $(1.60)$ & $(0.62)$ & $(0.54)$ \\
\hline \multirow[t]{2}{*}{ CFO_ATA } & -0.006 & 0.033 & 0.027 \\
\hline & $(-0.12)$ & $(0.24)$ & $(0.63)$ \\
\hline \multirow[t]{2}{*}{ Opercycle } & $1.49 \cdot 10^{-6}$ & $2.65 \cdot 10^{-5}$ & $9.50 \cdot 10^{-7}$ \\
\hline & $(0.09)$ & $(0.47)$ & $(0.11)$ \\
\hline \multirow[t]{2}{*}{ Intercept } & $-0.250 * *$ & $-0.315^{* *}$ & -0.047 \\
\hline & $(-2.35)$ & $(-2.19)$ & $(-0.90)$ \\
\hline Industry dummies & Yes & Yes & Yes \\
\hline $\mathbf{R}^{2}$ & 0.254 & 0.350 & 0.106 \\
\hline $\mathbf{F}$ & 3.36 & 3.19 & 2.12 \\
\hline $\mathbf{p}>\mathbf{F}$ & 0.000 & 0.000 & 0.005 \\
\hline Obs. & 500 & 230 & 270 \\
\hline
\end{tabular}

$* * *, * *, *$ denote significance at the $1 \%, 5 \%$ and $10 \%$ level, respectively. See Table 1 for definitions of variables.

Higher FRQ enhances investment efficiency. For overinvestment firms, a higher FRQ reduces this overinvestment; but for underinvestment firms, FRQ has no significant effect. STDebt increases investment efficiency in the two contexts: a greater use of short-term debt reduces overinvestment and underinvestment problems. The remaining control variables have the expected signs.

\subsubsection{Investment efficiency model with 25 and 75 STDebt percentiles}

In this section, we employ two alternative measures to interact FRQ and debt maturity: first, we divide our sample between those firms that have STDebt levels below percentile 25 (48\%), in which case DumSTDebt takes value 1, and firms that have short- 
term debt levels above this percentile, in which case DumSTDebt takes value 0. Second, we separate the sample between those firms that present short-term debt levels above percentile 75 (77\%), in which case the variable takes value 1, and firms below this level, in which case the variable takes value 0 . In Table 7 we show the results for the estimation of equation (2) when adopting the percentile 25 as short-term debt dummy.

Table 7. Regression of investment efficiency on FRQ, debt maturity, and interaction (II)

\begin{tabular}{|c|c|c|c|}
\hline & InvEff & Overinvestment & Underinvestment \\
\hline \multirow[t]{2}{*}{ Aggreg } & $0.047 * * *$ & $0.077 * * *$ & $-8.448 \cdot 10^{-4}$ \\
\hline & $(3.56)$ & $(6.05)$ & $(-0.16)$ \\
\hline \multirow[t]{2}{*}{ STDebt } & $0.222 * * *$ & $0.277 * * *$ & $0.066^{* *}$ \\
\hline & $(6.26)$ & $(3.75)$ & $(2.33)$ \\
\hline \multirow[t]{2}{*}{ FRQ*DumSTDebt } & $0.144 * * *$ & $0.132 * * *$ & $0.031 * *$ \\
\hline & $(3.84)$ & $(3.86)$ & $(2.12)$ \\
\hline \multirow{2}{*}{ LnSales } & -0.004 & -0.005 & $-0.005 *$ \\
\hline & $(-0.78)$ & $(-0.41)$ & $(-1.69)$ \\
\hline \multirow[t]{2}{*}{ LnAge } & 0.013 & 0.021 & $0.006^{* *}$ \\
\hline & $(0.92)$ & $(0.78)$ & $(1.68)$ \\
\hline \multirow[t]{2}{*}{ Tang } & $-0.262 * * *$ & $-0.344 * * *$ & -0.026 \\
\hline & $(-3.15)$ & $(-11.37)$ & $(-0.60)$ \\
\hline \multirow[t]{2}{*}{ StdCFO } & -0.032 & -0.172 & -0.046 \\
\hline & $(-0.29)$ & $(-0.90)$ & $(-1.17)$ \\
\hline \multirow{2}{*}{ StdSales } & -0.148 & -0.276 & 0.003 \\
\hline & $(-1.50)$ & $(-1.22)$ & $(0.05)$ \\
\hline \multirow[t]{2}{*}{ QTobin } & 0.002 & 0.012 & 0.001 \\
\hline & $(0.21)$ & $(0.50)$ & $(0.20)$ \\
\hline \multirow[t]{2}{*}{$\mathbf{Z}$} & $0.012 * *$ & $0.015^{*}$ & 0.001 \\
\hline & $(2.23)$ & $(1.07)$ & $(0.53)$ \\
\hline \multirow[t]{2}{*}{ Loss } & 0.038 & 0.043 & 0.001 \\
\hline & (1.19) & $(0.49)$ & $(0.12)$ \\
\hline \multirow[t]{2}{*}{ CFO_ATA } & -0.004 & -0.007 & 0.036 \\
\hline & $(-0.06)$ & $(-0.04)$ & $(0.75)$ \\
\hline \multirow[t]{2}{*}{ Opercycle } & $4.32 \cdot 10^{-6}$ & $3.15 \cdot 10^{-5}$ & $-1.30 \cdot 10^{-6}$ \\
\hline & $(0.24)$ & $(0.58)$ & $(-0.15)$ \\
\hline \multirow[t]{2}{*}{ Intercept } & $-0.241 * *$ & $-0.316 * *$ & $-0.055 * *$ \\
\hline & $(-2.25)$ & $(-2.32)$ & $(-1.04)$ \\
\hline Industry dummies & Yes & Yes & Yes \\
\hline Test $B_{1}+B_{3}$ & $27.14 * * *$ & $50.78 * * *$ & $3.00 *$ \\
\hline $\mathbf{R}^{2}$ & 0.322 & 0.394 & 0.101 \\
\hline $\mathbf{F}$ & 3.78 & 4.01 & 2.08 \\
\hline $\mathbf{p}>\mathbf{F}$ & 0.000 & 0.000 & 0.005 \\
\hline Obs. & 500 & 230 & 270 \\
\hline
\end{tabular}

$* * *, * *, *$ denote significance at the $1 \%, 5 \%$ and $10 \%$ level, respectively. See Table 1 for definitions of variables.

$F R Q$ variable is the aggregate measure of three proxies; DumSTDebt takes value 1 if short-term debt is lower than the 25 percentile $(0.48)$, and 0 otherwise. For the remaining variables see Table1.

The results obtained confirm the previous analysis. For those firms that have lower short-term debt, the effect of FRQ on investment efficiency is determined by $\beta_{1}+\beta_{3}=0.19(p<0.01)$, whereas for firms that have a higher degree of short-term debt the FRQ effect on efficiency is smaller (0.05). 
For companies that overinvest and present lower short-term debt, the FRQ repercussion is $\beta_{1}+\beta_{3}=0.21(\mathrm{p}<0.01)$, which is greater than for companies with higher short-term debt $(0.07)$.

For companies that underinvest and have lower short-term debt, FRQ repercussion on underinvestment efficiency is provided by $\beta_{1}+\beta_{3}=0.03 \quad(\mathrm{p}<0.01)$, while for those companies with a greater degree of short-term debt the FRQ effect on underinvestment is not significant.

In Table 8 we perform a similar analysis, but taking percentile 75 as a dummy variable of short-term debt.

Table 8. Regression of investment efficiency on FRQ, debt maturity, and interaction (III)

\begin{tabular}{|c|c|c|c|}
\hline & InvEff & Overinvestment & Underinvestment \\
\hline \multirow[t]{2}{*}{ Aggreg } & $0.115 * * *$ & $0.155 * * *$ & $5.17 \cdot 10^{-4}$ \\
\hline & $(3.46)$ & $(5.47)$ & $(0.04)$ \\
\hline \multirow[t]{2}{*}{ STDebt } & $0.192 * * *$ & $0.262 * * *$ & $0.052 *$ \\
\hline & $(5.25)$ & $(3.59)$ & $(1.81)$ \\
\hline \multirow{2}{*}{ FRQ*DumSTDebt } & $-0.090 * *$ & $-0.100 * *$ & 0.003 \\
\hline & $(-2.37)$ & $(-2.11)$ & $(0.26)$ \\
\hline \multirow[t]{2}{*}{ LnSales } & -0.003 & -0.006 & -0.004 \\
\hline & $(-0.57)$ & $(-0.44)$ & $(-1.43)$ \\
\hline \multirow[t]{2}{*}{ LnAge } & 0.018 & 0.024 & 0.006 \\
\hline & $(1.26)$ & $(0.87)$ & $(1.38)$ \\
\hline \multirow[t]{2}{*}{ Tang } & $-0.314 * * *$ & $-0.393 * * *$ & -0.035 \\
\hline & $(-4.33)$ & $(-7.68)$ & $(-0.77)$ \\
\hline \multirow{2}{*}{ StdCFO } & 0.017 & -0.113 & -0.037 \\
\hline & $(0.14)$ & $(-0.48)$ & $(-0.99)$ \\
\hline \multirow[t]{2}{*}{ StdSales } & $-0.145^{*}$ & -0.261 & -0.007 \\
\hline & $(-1.89)$ & $(-1.38)$ & $(-0.12)$ \\
\hline \multirow[t]{2}{*}{ QTobin } & $-1.41 \cdot 10^{-4}$ & 0.024 & 0.001 \\
\hline & $(-0.02)$ & $(0.84)$ & $(0.23)$ \\
\hline \multirow[t]{2}{*}{$\mathbf{Z}$} & $0.014 * * *$ & 0.011 & 0.002 \\
\hline & $(2.66)$ & $(0.73)$ & $(0.63)$ \\
\hline \multirow[t]{2}{*}{ Loss } & $0.043 *$ & 0.043 & $-2.17 \cdot 10^{-4}$ \\
\hline & $(1.80)$ & $(0.59)$ & $(-0.02)$ \\
\hline \multirow[t]{2}{*}{ CFO_ATA } & 0.004 & 0.029 & 0.032 \\
\hline & $(0.08)$ & $(0.19)$ & $(0.68)$ \\
\hline \multirow[t]{2}{*}{ Opercycle } & $9.78 \cdot 10^{-6}$ & $4.48 \cdot 10^{-5}$ & $-1.98 \cdot 10^{-6}$ \\
\hline & $(0.64)$ & $(0.84)$ & $(-0.23)$ \\
\hline \multirow[t]{2}{*}{ Intercept } & $-0.264 * * *$ & $-0.325^{*}$ & -0.054 \\
\hline & $(-2.72)$ & $(-2.22)$ & $(-1.03)$ \\
\hline Industry dummies & Yes & Yes & Yes \\
\hline Test $B_{1}+B_{3}$ & $6.03 * * *$ & $5.54 * *$ & 0.91 \\
\hline $\mathbf{R}^{2}$ & 0.280 & 0.369 & 0.092 \\
\hline $\mathbf{F}$ & 3.58 & 4.13 & 1.85 \\
\hline $\mathbf{p}>\mathbf{F}$ & 0.000 & 0.000 & 0.016 \\
\hline Obs & 500 & 230 & 270 \\
\hline
\end{tabular}

$* * *, * *, *$ denote significance at the $1 \%, 5 \%$ and $10 \%$ level, respectively. See Table 1 for definitions of variables.

$F R Q$ variable is the aggregate measure of three proxies; DumSTDebt takes value 1 if short-term debt is higher than the 75 percentile (0.77), and 0 otherwise. For the remaining variables see Table1. 
We observe the same results as before: as firms increase the level of short-term debt, the influence of FRQ on investment efficiency decreases. Hence, if short-term debt is reduced, financial reporting quality takes a more active role in efficiency, whereas if short-term debt increases, the role of FRQ declines. In short, we conclude that both mechanisms play a substitutive role in enhancing investment efficiency.

\subsubsection{Endogeneity issues}

In this section we consider the potential endogeneity issue between short-term debt and financial reporting quality. Recently, García-Teruel et al. (2010) suggest that firms with higher accruals quality can obtain a longer maturity than those firms with lower accruals quality. To solve this possible concern of endogeneity between debt maturity and FRQ, we estimate our models using a two-stage regression. With this procedure, we estimate, in the first stage, the short-term debt level for each firm and use this estimate in the general model of investment efficiency. We adopt the following model in the first stage:

$$
\begin{aligned}
\text { STDebt }_{\mathrm{i}, \mathrm{t}}= & \beta_{0}+\beta_{1} \mathrm{FRQ}_{\mathrm{i}, \mathrm{t}}+\beta_{2} \mathrm{Z}_{\mathrm{i}, \mathrm{t}}+\beta_{3} \mathrm{Z}_{\mathrm{i}, \mathrm{t}}^{2}+\beta_{4} \operatorname{Growp}_{\mathrm{i}, \mathrm{t}}+\beta_{5} \mathrm{AM}_{\mathrm{i}, \mathrm{t}}+ \\
& \beta_{6} \operatorname{LnSize}_{\mathrm{i}, \mathrm{t}}+\beta_{7} \operatorname{LnAge}_{\mathrm{i}, \mathrm{t}}+\beta_{8} \operatorname{Tax}_{\mathrm{i}, \mathrm{t}}+\beta_{9} \operatorname{Lev}_{\mathrm{i}, \mathrm{t}}+ \\
& \beta_{10} \operatorname{IntDif}_{\mathrm{i}, \mathrm{t}}+\beta_{11} \operatorname{StdSales}_{\mathrm{i}, \mathrm{t}}+\varepsilon_{\mathrm{i}, \mathrm{t}}
\end{aligned}
$$

where STDebt is the ratio of short-term debt over total debt. FRQ is the aggregate proxy of financial reporting quality; $\mathrm{Z}$ is the financial strength; Growp is growth options, expressed by Tobin's q; AM is asset maturity, calculated by Jun and Jen (2003)'s model; LnSize is firm size, measured by the log of market value; LnAge is the log of age; Tax is the corporate tax rate; Lev is the level of debt; Int_Dif is the interest rate differential between long (10 year) and short (1 year) debt; StdSales is the standard deviation of sales from $\mathrm{t}-2$ to $t$. The results of the first stage confirm those obtained by García-Teruel et al. (2010). Higher financial reporting quality is associated with a reduction of shortterm debt. In the first column of table 9 we present the results of our model, replacing the original short-term debt variable by its estimation in the equation (8).

After controlling for the possible endogeneity of short-term debt and FRQ, our findings are not affected. The results corroborate the hypotheses that higher financial reporting quality and higher use of short-term debt help to improve investment efficiency, and that the effect of financial reporting quality on investment efficiency is higher for those firms with lower short-term debt $\left(\beta_{3}<0\right)$, thus confirming our previous results about the substitution role of FRQ and short-term debt. 
Table 9. Two-stage regression (1), Reestimation of variables (2), and GMM(3)

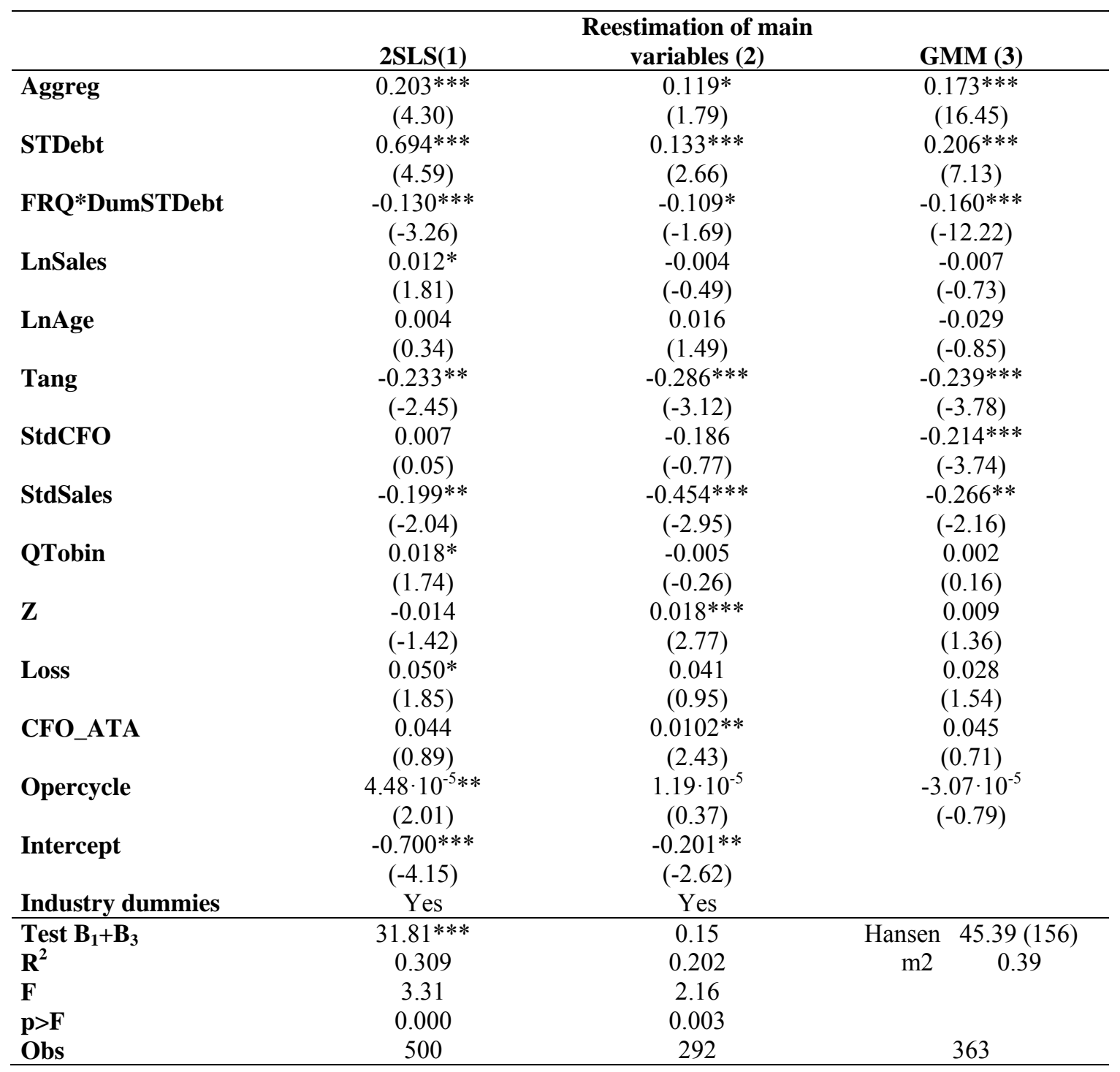

$* * *, * *, *$ denote significance at the $1 \%, 5 \%$ and $10 \%$ level, respectively. See Table 1 for definitions of variables.

The dependent variable in all models is investment efficiency; $F R Q$ variable is the aggregate measure of three proxies; DumSTDebt takes value 1 if estimated short-term debt is higher than the median (0.61), and 0 otherwise.

Model 1: STDebt is the estimated variable in the first stage.

Model 2: FRQ and STDebt variables are calculated as the mean from t-2 to t.

Model 3: Hansen is the test for over-identifying restrictions distributed asymptotically under null hypothesis of validity of instruments as chi-squared. Degrees of freedom in brackets.

$\mathrm{m}_{2}$ is test for second-order serial autocorrelation in residuals in first differences under null hypothesis of no serial correlation. For the remaining variables see Table1. 


\subsubsection{Main variables reestimation}

Since discretionary accruals are the central components of FRQ, and positive discretionary accruals that overstate earnings in one year are followed by negative discretionary accruals due to the reversion process of accruals, we reconsider our aggregate measure of FRQ and calculate, following Hutton et al. (2009), a new measure of FRQ as the average, from t-2 to t, of the aggregate FRQ measure. With this approach, we aim to solve the reversion process of accruals and assess the robustness of results with a variable that reflects the tendency of the firm to manipulate earnings across a three-year horizon. Likewise, for homogeneity, we also calculate the other main variable of our study, STDebt, as the average from $\mathrm{t}-2$ to $t$.

Taking these alternative specifications into consideration, the tabulated results in column 2 of table 9 are similar to those previously reported. In those firms with lower STDebt, FRQ and STDebt improve investment efficiency ( $\beta_{1}$ and $\left.\beta_{2}>0\right)$. However, in those firms with higher use of short-term debt, the FRQ effect is not significant $\left(\beta_{1}+\beta_{3}\right.$ is not significantly different from zero).

\subsubsection{Alternative estimation method}

Finally, we repeat our analysis by using the generalized method of moments (GMM), which allows us to control for endogeneity by using instruments. We use the two-step procedure developed by Arellano and Bond (1991), and use as instruments all the righthand side variables lagged twice. This approach assumes that there is no second-order serial correlation in the errors in first differences, which we check with the test for the absence of second-order serial correlation proposed by Arellano and Bond (1991). Likewise, we employ the Hansen test for over-identifying restrictions, which tests for the absence of correlation between the instruments and the error term. Since a minimum of 5 consecutive years is required, we lose some observations and thus can estimate only the general model of investment efficiency, and with a sample of 363 observations:

$$
\begin{aligned}
\text { InvEff }_{\mathrm{i}, \mathrm{t}}= & \beta_{1} \text { FRQ }_{\mathrm{i}, \mathrm{t}}+\beta_{2} \text { STDebt }_{\mathrm{i}, \mathrm{t}}+\beta_{3}\left(\mathrm{FRQ}_{\mathrm{i}, \mathrm{t}}{ }^{*} \text { DumSTDebt }_{\mathrm{i}, \mathrm{t}}\right)+ \\
& \beta_{4} \text { LnSales }_{\mathrm{i}, \mathrm{t}}+\beta_{5} \text { LnAge }_{\mathrm{i}, \mathrm{t}}+\beta_{6} \text { Tang }_{\mathrm{i}, \mathrm{t}}+\beta_{7} \text { StdCFO }_{\mathrm{i}, \mathrm{t}}+ \\
& \beta_{8} \text { StdRevenues }_{\mathrm{i}, \mathrm{t}}+\beta_{9} \text { QTobin }_{\mathrm{i}, \mathrm{t}}+\beta_{10} \mathrm{Z}_{\mathrm{i}, \mathrm{t}}+\beta_{11} \text { Loss }_{\mathrm{i}, \mathrm{t}}+ \\
& \beta_{12} \text { CFO_ATA }_{\mathrm{i}, \mathrm{t}}+\beta_{13} \text { Opercycle }_{\mathrm{i}, \mathrm{t}}+\eta_{\mathrm{i}}+\lambda_{\mathrm{t}}+\mathrm{v}_{\mathrm{i}, \mathrm{t}}
\end{aligned}
$$

where the variables are defined as in equation (1), and $\eta_{i}$ (unobservable heterogeneity) is designed to measure unobservable firms' characteristics that have a significant impact on investment efficiency. These attributes are different across firms but are constant for each firm. $\lambda_{t}$ are temporary dummy variables that change over time, but are the same for all firms in each year considered. Finally, $v_{i, t}$ is the error term. 
Our results, reported in the third column of table 9, remain unaltered. FRQ and STDebt are mechanisms that improve investment efficiency $\left(\beta_{1}\right.$ and $\left.\beta_{2}>0\right)$, and that present a substitutive effect $\left(\beta_{3}<0\right)$, so the effect of FRQ is higher in those firms with lower STDebt. The Arellano-Bond and Hansen tests validate the use of this estimation method, because we assume the null hypothesis of no second-order serial correlation in the errors in first differences, and of no correlation between the instruments and the error term, respectively.

\section{Conclusions}

In this paper we analyze the effect of FRQ and debt maturity, and also as their combined effect, on investment efficiency, using a representative sample of Spanish listed firms for the period 1998-2008. The results indicate that higher FRQ and higher use of short-term debt (lower debt maturity) increase investment efficiency. However, if we distinguish between overinvestment and underinvestment, FRQ plays a role in reducing overinvestment. In contrast, lower debt maturity is a mechanism that contributes positively to improving investment efficiency in both scenarios.

In addition, we find evidence that FRQ and lower debt maturity have a substitute relationship in improving investment efficiency: in those firms with lower short-term debt the FRQ effect on investment efficiency is higher than for those firms with a higher degree of short-term debt.

These findings suggest that in firms with lower FRQ, debt maturity is the main mechanism that is used by creditors to control managers' behaviour and to avoid expropriation. On the other hand, in those firms that present higher FRQ, accounting information may be used to monitor investment inefficiency problems. 


\section{References}

Abel, A., 1983. Optimal investment under uncertainty. American Economic Review 73, 228233.

Altman, E., 1968. Financial ratios, discriminant analysis and the prediction of corporate bankruptcy. The Journal of Finance 23, 589-609.

Arellano, M., Bond, S., 1991. Some Tests of Specification for Panel Data: Monte Carlo Evidence and An Application to Employment Equations. Review of

Economics Studies 58, 277-297.

Barclay, M.J., Smith, C.W., 1995. The maturity structure of corporate debt. The Journal of Finance 50, 609-631.

Berger, A., Udell, G., 1998. The economics of small business finance: the roles of private equity and debt markets in the financial growth cycle. Journal of Banking \& Finance 22, 613-73.

Bertrand, M., Mullainathan, S., 2003. Enjoying the quiet life? Corporate governance and managerial preference. Journal of Political Economy 111, 1043-1075.

Bharath, S.T., Sunder, J., Sunder, S.V., 2008. Accounting quality and debt contracting. The Accounting Review 83, 1-28.

Bhattacharya, U., Daouk, H., Welker, M., 2003. The world pricing of earnings opacity. The Accounting Review 78, 641-678.

Biddle, G., Hilary, G., 2006. Accounting quality and firm-level capital investment. The Accounting Review 81, 963-982.

Biddle, G., Hilary, G., Verdi, R.S., 2009. How does financial reporting quality relate to investments efficiency?. Journal of Accounting and Economics 48,112-131.

Bushman, R.M., Smith, A.J., 2001. Financial accounting information and corporate governance. Journal of Accounting and Economics 32, 237-333.

Chen, F., Hope, O., Li, Q., Wang, X., 2011. Financial reporting quality and investment efficiency of private firms in emerging markets. The Accounting Review 86, 1255-1288.

Childs, P.D., Mauer, D.C., Ott, S.H., 2005. Interactions of corporate financing and investment decisions: the effects of agency conflicts. Journal of Financial Economics 76, 667-690.

Crotty, J.R., 1992. Neoclassical and Keynesian approaches to the theory of investment. Journal of Post Keynesian Economics 14, 483-496.

Datta, S., Iskandar-Datta, M., Raman, K., 2005. Managerial stock ownership and maturity structure of corporate debt. The Journal of Finance 60, 2333-2350.

Dechow, P., Dichev, I., 2002. The quality of accruals and earnings: the role of accrual estimation errors. The Accounting Review 77, 35-59.

Diamond D.W., 1991. Debt maturity structure and liquidity risk. Quarterly Journal of Economics 106, 709-737.

Diamond, D.W., 1993. Seniority and maturity of debt contracts. Journal of Financial Economics 33, 341-68.

D’Mello, R., Miranda, M., 2010. Long-term debt and overinvestment agency problem. Journal of Banking \& Finance 34, 324-335.

Flannery, M.J., 1986. Asymmetric information and risky debt maturity choice. The Journal of Finance 41, 19-37. 
Francis, J., LaFond, R., Olsson, P.M., Schipper, K., 2004. Cost of equity and earnings attributes. The Accounting Review 79, 967-1010.

Francis, J., LaFond, R., Olsson, P.M., Schipper, K., 2005. The market pricing of accruals quality. Journal of Accounting and Economics 39, 295-327.

García-Lara, J.M., García-Osma, B., Penalva, F., 2010. Accounting conservatism and firm investment efficiency. Working paper.

García-Marco, T., Ocaña, C., 1999. The effect of bank monitoring on the investment behavior of Spanish firms. Journal Banking \& Finance 23, 1579-1603.

García-Teruel, P.J., Martínez-Solano, P., Sánchez-Ballesta, J.P., 2010. Accruals quality and debt maturity structure. Abacus 46, 188-210.

Gordon, M.J., 1992. The Neoclassical and a post Keynesian theory of investment. Journal of Post Keynesian Economics 14, 425-443.

Guedes, J., Opler, T., 1996. The determinants of the maturity of corporate debt issues. The Journal of Finance 51, 1809-1833.

Hayashi, F., 1982. Tobin's marginal q and average q: a neoclassical interpretation. Econometrica 50, 213-224.

Healy, P.M., Palepu, K.G., 2001. Information asymmetry, corporate disclosure, and the capital markets: A review of the empirical disclosure literature. Journal of Accounting and Economics 31, 405-440.

Hope, O., Thomas, W.B., 2008. Managerial empire building and firm disclosure. Journal of Accounting Research 46, 591-626.

Hubbard, R.G., 1998. Capital-market imperfections and investment. Journal of Economic Literature 36, 193-225.

Hutton, A.P., Marcus, A.J., Tehranian, H., 2009. Opaque financial reports, R2, and crash risk. Journal of Financial Economics 94, 67-86.

Jensen, M., Meckling, W.H., 1976. Theory of the firm: managerial behaviour, agency costs and ownership structure. Journal of Financial Economics 3, 305-360.

Jones, J., 1991. Earnings management during import relief investigations. Journal of Accounting Research 29, 193-228.

Jun, S. G., Jen, F.C., 2003. Trade-Off Model on Debt Maturity Structure. Review of Quantitative Finance and Accounting 20, 5-34.

Kasznik, R., 1999. On the association between voluntary disclosure and earnings management. Journal of Accounting Research 37, 57-81.

Lai, K.W., 2011. The cost of debt when all-equity firms raise finance: the role of investment opportunities, audit quality and debt maturity. Journal of Banking \& Finance 35, 1931-1940.

Lambert, R., Leuz, C., Verrecchia, R., 2007. Accounting information, disclosure, and the cost of capital. Journal of Accounting Research 45, 385-420.

Leuz, C, Nanda, D., Wysocki, P.D., 2003. Earnings management and Investor protection: an international comparison. Journal of Financial Economics 69, 505-527.

McNichols, M., Stubben, S., 2008. Does earnings management affect firms' investment decisions. The Accounting Review 86, 1571-1603.

Myers, S.C., 1977. Determinants of corporate borrowing. Journal of Financial Economics 5, $147-175$. 
Myers, S.C., Majluf, N.S., 1984. Corporate financing and investment decisions when firms have information that investors do not have. Journal of Financial Economics 13, 187-221.

Ortiz-Molina, H., Penas, M.F., 2008. Lending to small businesses: the role of the loan maturity in addressing information problems. Small Business Economics 30, 361-383.

Parrino, R., Weisbach, M.S., 1999. Measuring investment distortions arising from stockholderbondholder conflicts. Journal of Financial Economics 53, 3-42.

Petersen, M.A., 2009. Estimating standard errors in finance panel data sets: comparing approaches. The Review of Financial Studies 22, 435-480.

Rajan, R.G., 1992. Insiders and outsiders: the choice between informed and arm's-length debt. The Journal of Finance 47, 1367-1400.

Stiglitz, J., Weiss, A., 1981. Credit rationing in markets with imperfect information. American Economic Review 71, 393-410.

Yoshikawa, H., 1980. On the "q" theory of investment. American Economic Review 70, 739743. 


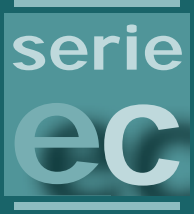

\section{I vie}

Guardia Civil, 22 - Esc. 2, 1음

46020 Valencia - Spain

Phone: +34 963190050

Fax: +34 963190055

Website: http:/ / www.ivie.es

E-mail: publicaciones@ivie.es 